\title{
Morphological Studies on the Triatoma brasiliensis Neiva, 1911 (Hemiptera, Reduviidae, Triatominae) Genital Structures and Eggs of Different Chromatic Forms
}

\author{
Jane Costa/ ${ }^{+}$, Ortrud Monika Barth*, Verônica Marchon-Silva, Carlos Eduardo \\ de Almeida**, Maria Goreti Rosa Freitas-Sibajev***, Francisco Panzera****
}

\begin{abstract}
Coleção Entomológica, Departamento de Entomologia *Laboratório de Ultraestrutura Viral, Departamento de Virologia ***Laboratório de Sistemática Bioquímica, Departamento de Bioquímica e Biologia Molecular, Instituto Oswaldo Cruz, Av. Brasil 4365, 21045-900 Rio de Janeiro, RJ, Brasil **Departamento de Ecologia, Sociedade Barramansense de Ensino Superior ****Faculdade de Ciências, Seção de Genética Evolutiva,

Universidade de Montevidéu, Uruguai
\end{abstract}

Triatoma brasiliensis is considered one of the most important Chagas disease vectors being a widespread species in semiarid areas of northeastern Brazil. The species displays distinct chromatic patterns of the cuticle in different localities. Four populations were analyzed in this study: 1-Caico, Rio Grande do Norte, it will be called the brasiliensis population; 2-Espinosa, Minas Gerais, the melanica population; 3-Petrolina, Pernambuco, the macromelasoma population, and 4-Juazeiro, Bahia, the darker one in overall cuticle coloration, the Juazeiro population. In order to differentiate the four populations of T. brasiliensis, a comparative morphological analysis of external genital structures and of eggs were carried out. The analysis of the male genital structures evidenced minor individual structural variations that did not correlate with chromatic differences or the geographical origins, emphasizing the importance of examining sufficiently large and representative samples before using minor genital variations for taxonomic diagnosis. By scanning electron microscopy of the egg exochorion, each chromatic population presented a distinct ornamentation pattern. The melanica population differed mainly from the other populations studied since it had about 40.6\%, 69.6\% and 76.6\% more perforations, on each cell exochorion, than the brasiliensis, the Juazeiro and the macromelasoma populations respectively. In the melanica population the perforation layout is also peculiar, with densely distributed perforations over all the egg surface. Morphometric measures of the eggs showed statistically significant differences: the macromelasoma population presented the longest length $(2.43 \mathrm{~mm})$ while the shortest was recorded in the brasiliensis population $(2.29 \mathrm{~mm})$.

Key words: Triatoma brasiliensis - populations - morphology - external genital structures - eggs

Triatoma brasiliensis is widespread in semiarid areas of northeastern Brazil and is considered one of the most important Chagas disease vectors (Silveira et al. 1984). This species is chromatically variable, regarding its cuticle color (Lent \& Wygodzinsky 1979). Darker specimens from Espinosa (Minas Gerais) and Petrolina (Pernambuco) were given formal trinomials i.e., $T$. brasiliensis melanica Neiva \& Lent, 1941 and $T$. b. macromelasoma Galvão, 1956, respectively. These two populations were recognized as distinct from each other and from the lighter nominal subspecies from Caicó (Rio Grande do Norte) on the

Presented on the XX and XXIII Annual Meeting on Basic Research of Chagas Disease - Caxambu, MG, Brazil. Supported by CNPq and Fundação Nacional de Saúde. ${ }^{+}$Corresponding author. Fax: +55-21-590.3545

Received 12 November 1996

Accepted 6 May 1997 basis of chromatic characters of the external cuticle. A taxonomic key separating the distinct chromatic populations was created by Galvão (1956). Nonetheless Lent and Wygodzinsky (1979) stated that intergrading forms are frequent in this species and considered these subspecies as synonymy. A fourth distinct chromatic pattern was encountered in Juazeiro (Bahia) and will be refered to as the Juazeiro population.

With the aim of finding useful morphological parameters to differentiate these distinct populations of $T$. brasiliensis, we performed the analysis of male external genitalia, the scanning electron microscopy (SEM) and morphometry of eggs.

\section{MATERIALS AND METHODS}

Genital structures - Seven structures were studied: the paramere, the median process of the pygophore, the endosomal process, the articulatory apparatus, the phallosome, the phallosome support 
and the vesica. These structures were compared with the description of the genitalia of $T$. brasiliensis reported by Lent and Jurberg (1978). Forty adult males of four populations of $T$. brasiliensis were dissected and drawing of the external genital structures were made. Origins and chromatic characters of these specimens were as follows: 20 specimens of the brasiliensis color form from different localities: 4 from São João, Piauí; 3 from Arara, Ceará; 3 from Paraíba; 8 from Caicó, Rio Grande do Norte; 1 from Icó, Ceará; 1 from Quixadá, Ceará and 1 with unknown origin; 7 specimens of the melanica population from Espinosa, Minas Gerais; 5 specimens of the macromelasoma population from Petrolina, Pernambuco; 8 specimens of the Juazeiro population.

Slide-mounted preparations were deposited in the Entomological Collection of the Instituto Oswaldo Cruz under the registration numbers 2715 to 2720,2726 to 2730 and 2739 to 2746 .

Eggs - The eggs were obtained from colonies maintained at the Instituto Oswaldo Cruz Entomological Collection Laboratory. These colonies were started with specimens collected at the following localities: 1- Caicó, Rio Grande do Norte $\left(6^{\circ}\right.$ $27^{\prime} 30^{\prime \prime} \mathrm{S}$ and $37^{\circ} 05^{\prime} 52^{\prime \prime} \mathrm{W}$ ), the brasiliensis population, as described by Neiva 1911; 2- Espinosa, Minas Gerais (14'55'34'S and 42 $49^{\circ}$ '09'W), the melanica population, as described by Neiva \& Lent 1941; 3- Petrolina, Pernambuco (9²3'35'S and $40^{\circ} 30^{\prime} 27^{\prime \prime} \mathrm{W}$ ), the macromelasoma population, as described by Galvão 1956; 4- a fourth distinct population was collected in Junco, Juazeiro municipality, Bahia (9'29'49"S and 40'30'11' W), the Juazeiro population. This population has a color pattern close to description of T. b. macromelasoma, but with prothorax and legs entirely dark and, dark patches of hemelytron not reaching the costal margin. These colonies are being kept at room temperature $\left(\min 24^{\circ} \mathrm{C}, \max 35^{\circ} \mathrm{C}, \overline{\mathrm{X}}=32.5^{\circ} \mathrm{C}\right.$ and $\min 50 \%, \max 92 \%, \bar{X}=71.81 \% \mathrm{RH}$ ), fed fortnightly on normal mouse blood.

For SEM observations, 6 eggs of each population, were randomly picked up from a stock of more than 1,000 ecloded eggs of each colony, originated from more than 30 females of each population. The eggs were attached with a double face sealing tape on a metallic plate. They were sputtered with gold to be observed in a ZEISS electron microscope (model DSM-940) at 1,000x enlargement. The central zone of the exochorion, the body and the lid of the eggs were used in order to standardize the areas to be pictured. Thirty cells of these regions of each population were counted, for the number of perforations. For the morphometric studies, which included length, width and the ratio length/width,
30 eggs randomly picked up from the stock of eggs of each population were drawn and standard measurements were performed. For the statistical analysis, it was used: analysis of variance, KruskalWallis, T-Student and Mann-Whitney depending on the variable distribution and the number of groups.

\section{RESULTS}

Genital structures - The four populations presented individual variations in all structures analyzed: the parameres show some variation in the size of subapical projection. The median process of pygophore is strongly arched basely in all specimens and presents variation in the size of apical projection. The phallosome is variable in outline, its base either straight or from slightly to distinctly concave. The phallosome support is of variable length, with the basal plate struts fused apically (incompletely in some specimens) and internal margins either straight or sinuous. The gonopore process in the articulatory apparatus is open longitudinally on the internal surface and the sides either joined or divided at the apex. The lateral endosomal process is armed apically with 7-91 conspicuous denticles. The vesica in dorsal view is apically rounded to sub-triangular and variable in size .

Eggs - SEM: morphological differences in the body and the lid of the egg exochorion of the four populations were observed.

Body surface: melanica specimens presented a large number of perforations on each polygonal cell surface (Fig. 1B), with an average of 57.2 perforations per cell. This average is $40.6 \%$ greater than the observed for the brasiliensis population which presented an average of 34 perforations per cell (Fig. 1A). The specimens of the melanica population has about $69.6 \%$ more perforations than the specimens originated from Juazeiro population (Fig. 1D) with an average of 17.4 , and about $76.6 \%$ more than the specimens of the macromelasoma population (Fig. 1C), with an average of 13.4 perforations per cell. The perforations distribution of melanic specimens (Fig. 2B) was peculiar. They were packed and close to the edges. In the brasiliensis population only a few perforations are close to the edges; also as perforations approach the center of the cell, their frequency increase. According to the statistical analysis, it was evidenced a significant difference on the number of perforations to each group (Table I).

Lid surface: the lid exochorion in melanic specimens presents the largest number of perforations per cell, about 10 to 20 (Fig. 2B). Specimens of brasiliensis population present 2 to 6 perforations (Fig. 2A), while the other two populations show 

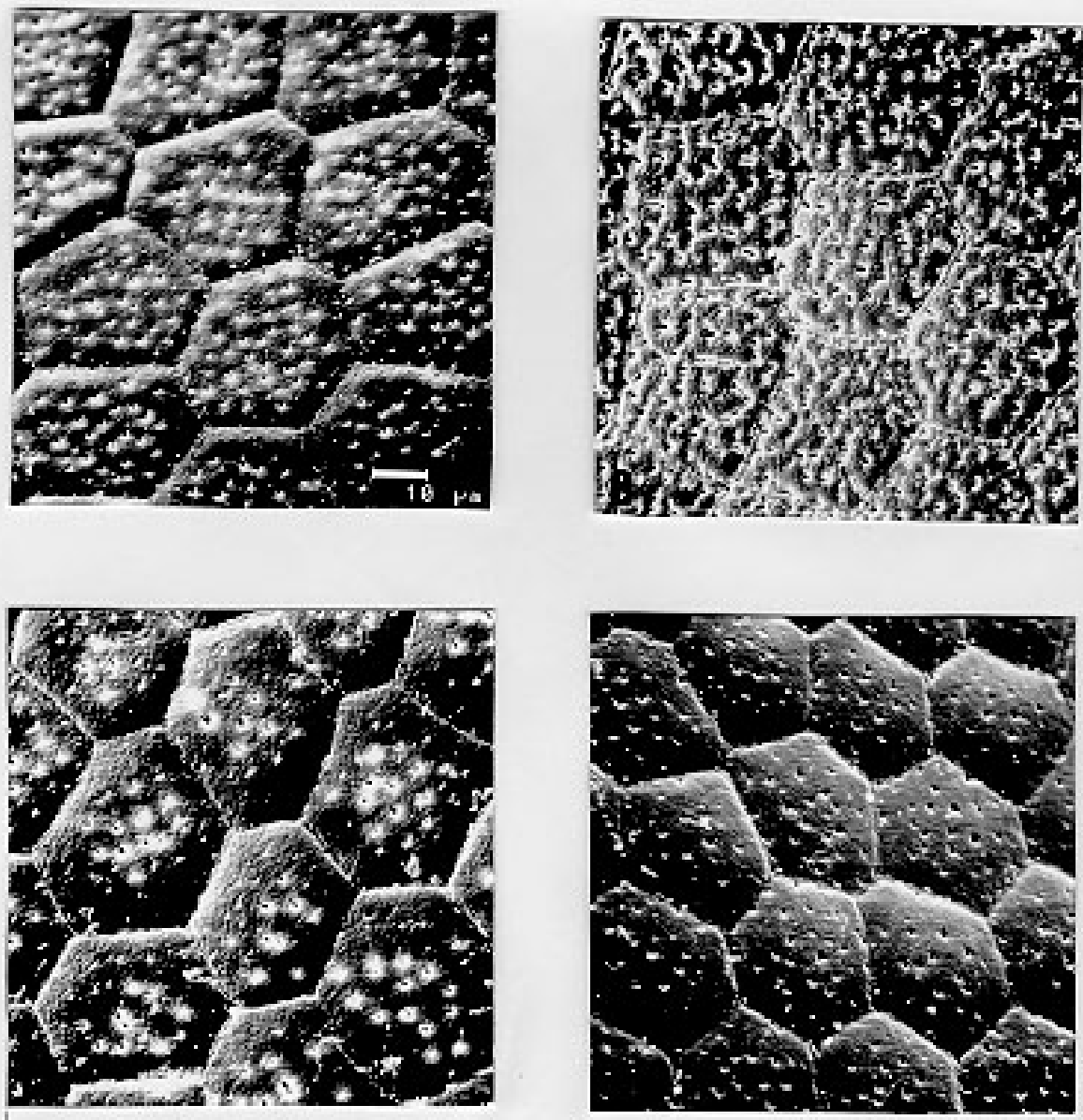

Fig. 1: exochorion of the egg bodies of four distinct populations of Triatoma brasiliensis. A- brasiliensis; B- melanica; Cmacromelasoma; D- Juazeiro.

TABLE I

Number of perfurations per cell of eggs of four distinct populations of Triatoma brasiliensis

\begin{tabular}{|c|c|c|c|c|}
\hline & brasiliensis & melanica & macromelasoma & Juazeiro \\
\hline $\min$. & 28 & 56 & 15 & 11 \\
\hline $\max$ & 40 & 59 & 20 & 17 \\
\hline $\bar{X}$ & 34 & 57.2 & 17.4 & 13.4 \\
\hline$S$ & 3.6765 & 1.0635 & 1.7733 & 1.9226 \\
\hline Krusk & \multicolumn{2}{|c|}{$\mathrm{X}_{3}^{2}=108.67$} & \multicolumn{2}{|c|}{$\mathrm{p}=0.0000$} \\
\hline
\end{tabular}

$\overline{\mathrm{X}}=$ average $; \mathrm{S}=$ standard deviation

only slightly perceived perforations (Figs $2 \mathrm{C}$ and 2D). Specimens of Juazeiro populations have cells with rounded corners, different from the polygonal form of the other populations.

Morphometrics - The largest length and width of the egg were observed in the macromelasoma population, with an average of $2.43 \mathrm{~mm}$ and 1.41 $\mathrm{mm}$, respectively. The smallest length was shown in the brasiliensis population with an average of 2.29 $\mathrm{mm}$, and the shortest width in the Juazeiro population with $1.30 \mathrm{~mm}$ average value. The greatest mean value length $\div$ width was seen in the Juazeiro specimens with an 1.82 average versus the shortest relation in the macromelasoma specimens. Length and width presented significant statistical differences up to the 5\% level among all the combinations studied, except for the melanic population versus the Juazeiro population (Table II). 

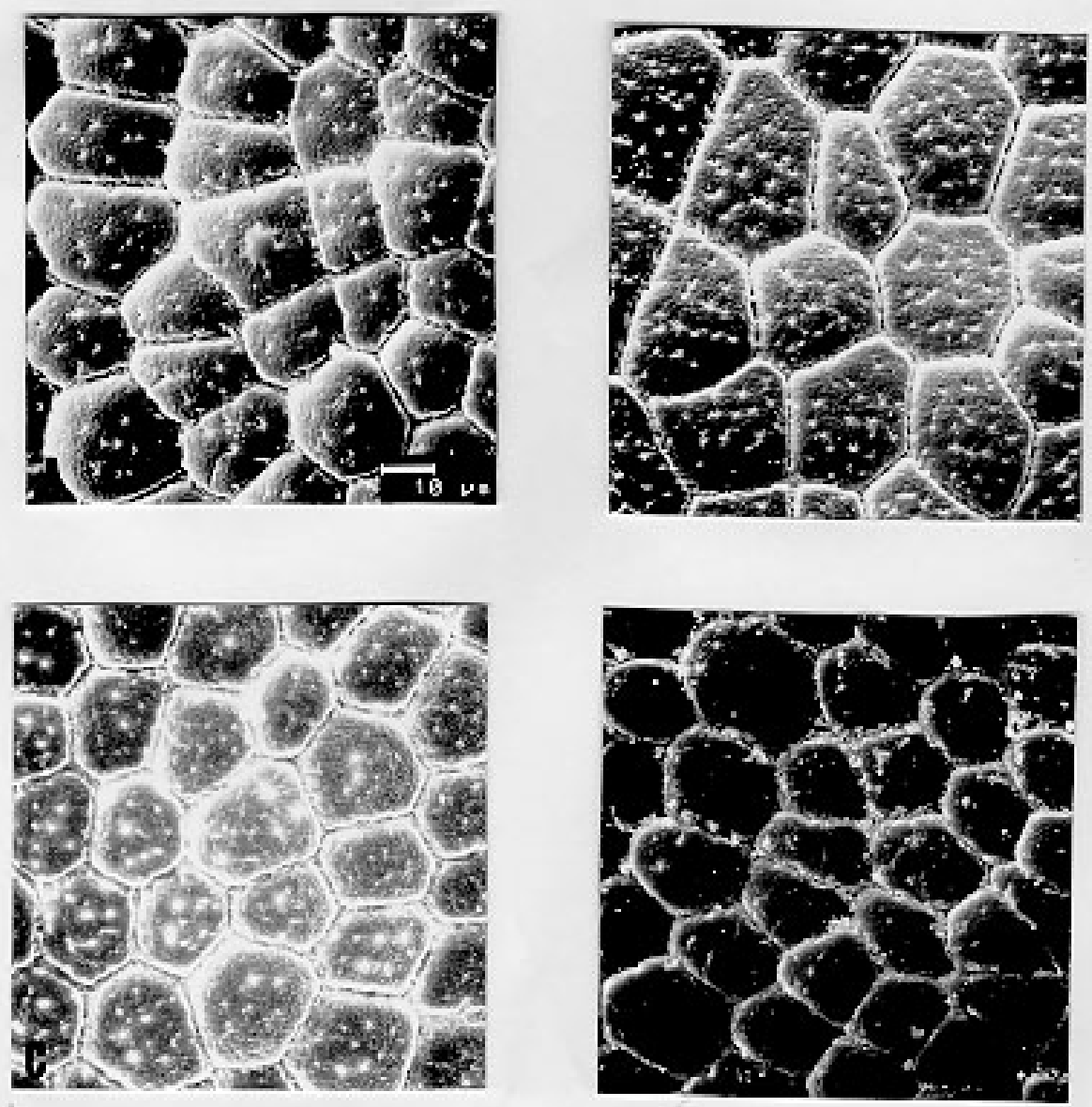

Fig. 2: exochorion of the egg lids of four distinct populations of Triatoma brasiliensis. A- brasiliensis; B- melanica; Cmacromelasoma; D- Juazeiro.

TABLE II

Egg morphometry of four distinct populations of Triatoma brasiliensis

\begin{tabular}{|c|c|c|c|c|c|c|}
\hline Measures & Oopulations & brasiliensis & melanica & macromelasoma & Juazeiro & Kruskal- Wallis \\
\hline \multirow{4}{*}{ 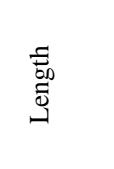 } & $\min$. & 2.15 & 2.20 & 2.24 & 2.16 & \multirow{4}{*}{$\begin{array}{c}\mathrm{X}_{3}^{2}=20.6006 \\
\mathrm{p}=0.0001\end{array}$} \\
\hline & $\max$ & 2.49 & 2.49 & 2.58 & 2.51 & \\
\hline & $\bar{X}$ & 2.30 & 2.36 & 2.43 & 2.36 & \\
\hline & $\mathrm{S}$ & 0.0913 & 0.0675 & 0.1179 & 0.0951 & \\
\hline \multirow{4}{*}{$\frac{5}{3}$} & $\min$. & 1.25 & 1.27 & 1.29 & 1.20 & \multirow{4}{*}{$\begin{array}{c}\mathrm{X}_{3}^{2}=45.4966 \\
\mathrm{p}=0.0000\end{array}$} \\
\hline & $\max$ & 1.40 & 1.44 & 1.53 & 1.36 & \\
\hline & $\bar{X}$ & 1.32 & 1.35 & 1.41 & 1.30 & \\
\hline & $\mathrm{S}$ & 0.0366 & 0.0418 & 0.0629 & 0.0469 & \\
\hline \multirow{4}{*}{ 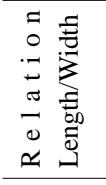 } & $\min$. & 1.59 & 1.67 & 1.56 & 1.71 & \multirow{4}{*}{$\begin{array}{c}\mathrm{X}_{3}^{2}=24.2445 \\
\mathrm{p}=0.0000\end{array}$} \\
\hline & $\max$ & 1.83 & 1.85 & 1.95 & 1.98 & \\
\hline & $\bar{X}$ & 1.73 & 1.75 & 1.72 & 1.82 & \\
\hline & $\mathrm{S}$ & 0.0517 & 0.0445 & 0.0832 & 0.0828 & \\
\hline
\end{tabular}




\section{DISCUSSION}

Studies on the male external genital structures, associated with other external morphological characters, have been an important tool for Triatominae taxonomy. Similar morphological species have been separated using these structures: Rhodnius stali and R. pictipes (Lent et al. 1993); T. maculata and T. pseudomaculata (Galvão 1973). Recently, Jurberg and Galvão (1997) used genital structures to describe a new genus in triatomines. At intraspecific level, Lent and Jurberg (1985) reported individual variations for $T$. infestans and $T$. dimidiata. The later species showed chromatic variations and their genital structures did not correlate with the distinct chromatic patterns.

In $T$. brasiliensis the minor individual variations of the male genitalia clearly did not correlate with the distinct chromatic population or the geographical origins. For example, the most readily quantifiable variable, number of denticles on the lateral endosomal process, varied from 7 to 91 in the sample as a whole and from 15 to 89 in two specimens from the same locality and of the same color pattern. In conclusion, morphological studies of the genitalia are unlikely to be useful for defining these four populations of $T$. brasiliensis. Along with reports of structural variations in $T$. infestans (Pires et al. 1995) these results also emphasize the importance of examining sufficiently large and representative samples before using minor genital variations for taxonomic diagnosis.

In triatomines, several reports on ornamentation of egg exochorion have demonstrated their importance as a tool for taxonomy at specific level (Galliard 1935, Gonçalves et al. 1985, Costa et al. 1991, Barata 1995). Barata (1981), described the exochorion morphology of eggs, using light microscopy and SEM, from 10 species of the genus Rhodnius, being this the most important contribution.

The previous results on the egg morphology of T. brasiliensis presented by Barth and Muth (1958) and by Jurberg et al. (1986) are in accordance to our results for the brasiliensis population. Different environmental conditions (available food sources, temperature and humidity) could affect direct or indirectly the egg morphology. But, in this study, the four populations have been maintained under the same environmental and feeding conditions. The number of eggs analyzed and its randomly selection from a large stock, originated from more than 30 females for each colony, also corroborate the morpho-structural differentiation observed at population level.

In the present study, morphometry provided significant differences among the populations of
T. brasiliensis, although overlapping of the minimum and maximum values for the different measures were observed. Hence, the possibility to separate $T$. brasiliensis populations based on the egg morphology was evidenced. Differences in the structural level, on the exochorion ornamentation, with different number of perforations and also on the shape of cells of the lid were shown.

The population differentiation detected by egg morphology is in agreement with several other data: the four populations showed homogeneity and stability of their chromatic pattern for several years in the colonies reared in the laboratory (Costa et al. 1996b); during the field collections, only one colour pattern was found in each locality. We did not record intermediate forms, reported by Lent and Wygodzinsky (1979). Maybe these intergrading forms could be present in the border lines where crossings among different colour patterns could be occuring; isoenzymatical data (Costa et al. 1997) suggested a clear genetic differentiation among these populations of T. brasiliensis, reaching Nei's genetic distance values correspondent to those found at interspecific level, for other phylogenetic related species (Pereira et al. 1996).

In order to broaden the knowledge on these different populations of $T$. brasiliensis, it will be important to define the geographical distribution, emphasizing the overlapping regions, determine the existence or non-existence of reproductive isolation mechanisms via directed crosses (Costa et al. 1996a) and to determine the population structures by other genetic markers such as chromosomes and DNA.

\section{ACKNOWLEDGMENTS}

To Dr Teresa Cristina M Gonçalves, for permission to analyze the insects of Herman Lent Hemiptera collection. To Drs Pedro Cabello and Nelson Chagas for the guidance on statistical procedures. To Dr Herman Lent for his valuable comments on the manuscript.

\section{REFERENCES}

Barata JMS 1981. Aspectos morfológicos de ovos de Triatominae. II Características macroscópicas e exocoriais de dez espécies do gênero Rhodnius Stal, 1859 (Hemiptera, Reduviidae). Rev Saúde Públ 15: 490-542.

Barata JMS 1995. Aspectos morfológicos de ovos de Triatominae, p. 55-58. In Proc Inter Workshop on Population Genetics and Control of Triatominae, Ecuador.

Barth R, Muth H 1958. Estudos anatômicos e histológicos sobre a família Triatominae (Heteroptera, Reduviidae). VII Parte: Observações sobre a superfície dos ovos das espécies mais importantes. Mem Inst Oswaldo Cruz 56: 197-208, figs. 1-23.

Costa JM, Jurberg J, Barth O 1991. Estudos morfológicos de Cavernicola lenti Barrett \& Arias 1985 (Hemi- 
ptera, Reduviidae, Triatominae). Mem Inst Oswaldo Cruz 86: 247-263.

Costa J, Marchon-Silva V, Almeida JR 1996a. Does hybridization clarify the taxonomic status of different melanic forms of Triatoma brasiliensis Neiva,1911 (Hemíptera- Reduviidae- Triatominae)? Mem Inst Oswaldo Cruz 91 (Suppl. I): 128.

Costa J, Marchon-Silva V, Freitas-Sibajev MGR, Pires MQ, Pacheco RS 1996b. Estudos isoenzimáticos detectam variação intra-especifica em Triatoma brasiliensis Neiva, 1911 (Reduviidae, Triatominae). Rev Soc Bras de Med Trop 29 (Suppl. I): 129.

Costa J, Freitas-Sibajev MGR, Marchon-Silva V, Pires MQ, Pacheco RS 1997. Isoenzymes detect variation in populations of Triatoma brasiliensis. Mem Inst Oswaldo Cruz 92 (in press).

Galliard H 1935. Recherches sur les Reduviidés Hématophages Rhodnius et Triatoma. V. Morphologie de l'oeuf des Triatomes. Ann Parasit hum comp XIII: 511-527.

Galvão AB 1956. Triatoma brasiliensis macromelasoma n. subsp. (Hemiptera, Reduviidae). Rev brasil de Malariol D trop 7: 455-457.

Galvão AB 1973. Contribuição ao conhecimento do Triatoma maculata (Erichson, 1848) e do Triatoma pseudomaculata Corrêa \& Espínola, 1964 (Hemiptera, Reduviidae). Rev Soc Bras Med Trop 7: 367380.

Gonçalves TCM, Jurberg J, Costa JM, Souza W 1985. Estudo morfológico comparativo de ovos e ninfas de Triatoma maculata (Erichson, 1848) e Triatoma pseudomaculata Corrêa e Espínola, 1964 (Hemiptera, Reduviidae, Triatominae). Mem Inst Oswaldo Cruz 80: 263-276.

Jurberg J, Galvão C 1997. Hermanlentia n. gen. da tribo Triatomini, com um rol de espécies de Triatominae
(Hemiptera, Reduviidae). Mem Inst Oswaldo Cruz 92: 181-185.

Jurberg J, Gonçalves TCM, Costa JM, Souza W 1986. Contribuição ao estudo morfológico de ovos e ninfas de Triatoma brasiliensis Neiva, 1911 (Hemiptera, Reduviidae, Triatominae). Mem Inst Oswaldo Cruz 81: 111-120.

Lent H, Jurberg J 1978. Estudo comparativo da genitália externa masculina de seis espécies de Triatoma Laporte, 1832 que mais freqüentemente habitam o domicílio humano no Brasil (Hemiptera, Reduviidae). Rev Brasil Biol 38: 931-944.

Lent H, Jurberg J 1985. Sobre a variação intra-específica em Triatoma dimiata (Latreille) e Triatioma infestans (Klug) (Hemiptera, Reduviidae). Mem Inst Oswaldo Cruz 80: 285-299.

Lent H, Jurberg J, Galvão C 1993. Rhodnius stali n.sp., afim de Rhodnius pictipes Stal, 1872 (Hemiptera, Reduviidae, Triatominae). Mem Inst Oswaldo Cruz 88: 605-614.

Lent H, Wygodzinsky P 1979. Revision of Triatominae (Hemiptera, Reduviidae), and their significance as vectors of Chagas disease. Bull Amer Mus Nat History, New York, 163: 520.

Pereira J, Dujardin JP, Salvatella R, Tibayrenc M 1996. Enzymatic variability and phylogenetic relatedness among Triatoma infestans, T. platensis, T. delpontei and T. rubrovaria. Heredity 77: 47-54.

Pires HHR, Barbosa SH, Jurberg J, Diotaiuti L 1995. Comparative studies of distinct populations of Triatoma infentans. V. Morphological patterns of the male genitalia. Mem Inst Oswaldo Cruz 90 (Suppl. I): 227.

Silveira AC, Feitosa VR, Borges R 1984. Distribuição de triatomíneos capturados no ambiente domiciliar, no período 1975/83, Brasil. Rev brasil de Malariol D trop 36: $15-312$. 